\title{
Assessing the risk of angiotensin receptor blockers on major cardiovascular events: a systematic review and meta-analysis of randomized controlled trials
}

Yara Wanas ${ }^{1 \dagger}$, Rim Bashir $^{1 \dagger}$, Nazmul Islam ${ }^{2^{*}}$ and Luis Furuya-Kanamori ${ }^{1,3}$

\begin{abstract}
Background: Angiotensin receptor blockers (ARBs) are commonly used as a treatment for many cardiovascular diseases, but their safety has been called into question. The VALUE trial found an increased risk of myocardial infarction in participants receiving ARBs compared to other antihypertensive. The aim of the meta-analysis was to synthetize the available evidence of randomised controlled trials (RCTs) and elucidate if ARBs increase the risk of cardiovascular events.

Methods: A comprehensive search was conducted to identify RCTs that assessed the safety of ARBs. Titles and abstracts of all papers were independently screened by two authors. Data extraction and quality assessment were also performed independently. The relative risk (RR) of all-cause mortality, myocardial infarction, and stroke were pooled using the IVhet model. Multiple sensitivity analyses were conducted to assess the effect of ARBs by restricting the analysis to different participants' characteristics.

Results: Forty-five RCTs comprising of 170,794 participants were included in the analysis. The pooled estimates revealed that ARBs do not increase the risk of all-cause mortality (RR 1.00; 95\% Cl 0.97-1.04), myocardial infarction (RR 1.01; 95\%Cl 0.96-1.06), and stroke (RR 0.92; 95\% Cl 0.83-1.01). The sensitivity analysis did not yield a particular group of patients at increased risk of cardiovascular events with ARBs. Risk of all-cause mortality and stroke decreased with ARB when the proportion of smokers in a population was < 25\% (RR $0.91 ; 95 \% \mathrm{Cl} 0.84-0.98$ ) and in females (RR 0.76; 95\% Cl 0.68-0.84), respectively.
\end{abstract}

Conclusions: ARBs do not increase the risk of major cardiovascular events and are safe for use in patients.

Keywords: Cardiovascular events, Angiotensin receptor blockers, Meta-analysis, Risk

\footnotetext{
* Correspondence: nislam@qu.edu.qa

†Yara Wanas and Rim Bashir joint first authors

${ }^{2}$ Department of Public Health, College of Health Sciences, QU Health, Qatar University, Doha, Qatar

Full list of author information is available at the end of the article
}

(c) The Author(s). 2020 Open Access This article is licensed under a Creative Commons Attribution 4.0 International License, which permits use, sharing, adaptation, distribution and reproduction in any medium or format, as long as you give appropriate credit to the original author(s) and the source, provide a link to the Creative Commons licence, and indicate if changes were made. The images or other third party material in this article are included in the article's Creative Commons licence, unless indicated otherwise in a credit line to the material. If material is not included in the article's Creative Commons licence and your intended use is not permitted by statutory regulation or exceeds the permitted use, you will need to obtain permission directly from the copyright holder. To view a copy of this licence, visit http://creativecommons.org/licenses/by/4.0/ The Creative Commons Public Domain Dedication waiver (http://creativecommons.org/publicdomain/zero/1.0/) applies to the data made available in this article, unless otherwise stated in a credit line to the data. 


\section{Background}

Cardiovascular diseases (CVDs) remain one of the most prevalent non-communicable diseases and impose a great burden on the healthcare systems. Globally, an estimated 16.7 million deaths in the year 2010 were attributed to CVD with projections showing a staggering 23.3 million deaths by 2030 [1]. Hypertension is the leading risk factor for CVD and it is associated with 57 million disability adjusted life years (DALYs) worldwide [2].

It is well known that the risk of major cardiovascular events can be reduced by a wide spectrum of antihypertensive drugs including angiotensin receptor blockers (ARBs) [3]. This type of drug works by inhibiting the angiotensin II receptors, thus causing systemic vasodilatation, thereby aiding in the reduction of blood pressure [4]. ARBs are one of the most common drugs used for controlling blood pressure, treating heart failure, and preventing kidney failure in people with diabetes or hypertension [5]. However, the safety of ARBs in comparison to other anti-hypertensive medications has been called into question.

The VALUE trial found that ARBs (valsartan) increased the risk of myocardial infarction (fatal and nonfatal) by $19 \%$ compared with calcium channel blockers (amlodipine) [6]. This observation led many researchers to examine cautiously the evidence surrounding ARBs and myocardial infarction. For example, the point estimate of the CHARM-alternative trial suggests a 36\% increase in myocardial infarction with candesartan (versus placebo) regardless of the reduction in blood pressure [7]. On the other hand, the TRANSCEND trial found an $8 \%$ decrease in risk of cardiovascular admissions for those on telmisartan compared to placebo [8].
Angiotensin-converting-enzyme (ACE) inhibitors are known to have a cardioprotective effect and the safety profile of ACE inhibitors have been shown not to differ from ARBs [9]. Hence it was unclear the mechanism that could explain an increase in risk of myocardial infarction with ARBs. Due to the wide use of ARBs for many CVDs and the contradictory results, we decided to conduct a systematic review and meta-analysis of randomised controlled trials (RCTs) to elucidate the cardiovascular safety profile of ARBs.

\section{Methods}

Findings of this systematic review and meta-analysis are presented according to PRISMA reporting guidelines [10].

\section{Search strategy and selection criteria}

A systematic search was conducted in PubMed in September 2018. The following search terms were included: randomized controlled trial, angiotensin receptor antagonist, cardiovascular disease, and mortality. The full search strategy is shown in the supplementary material (S1). To achieve a comprehensive evaluation of the published evidence, the systematic search was supplemented with a similarity search (i.e. the first 20 related citations of each included paper) as well as hand search of the reference lists of relevant studies. Titles and abstracts were uploaded on Rayyan (http://rayyan.qcri.org/) [11] for the screening process. Two authors (YW and RB) independently screened all the records by title and abstract. Disagreements were resolved through author consensus and involvement of a third author (LFK).

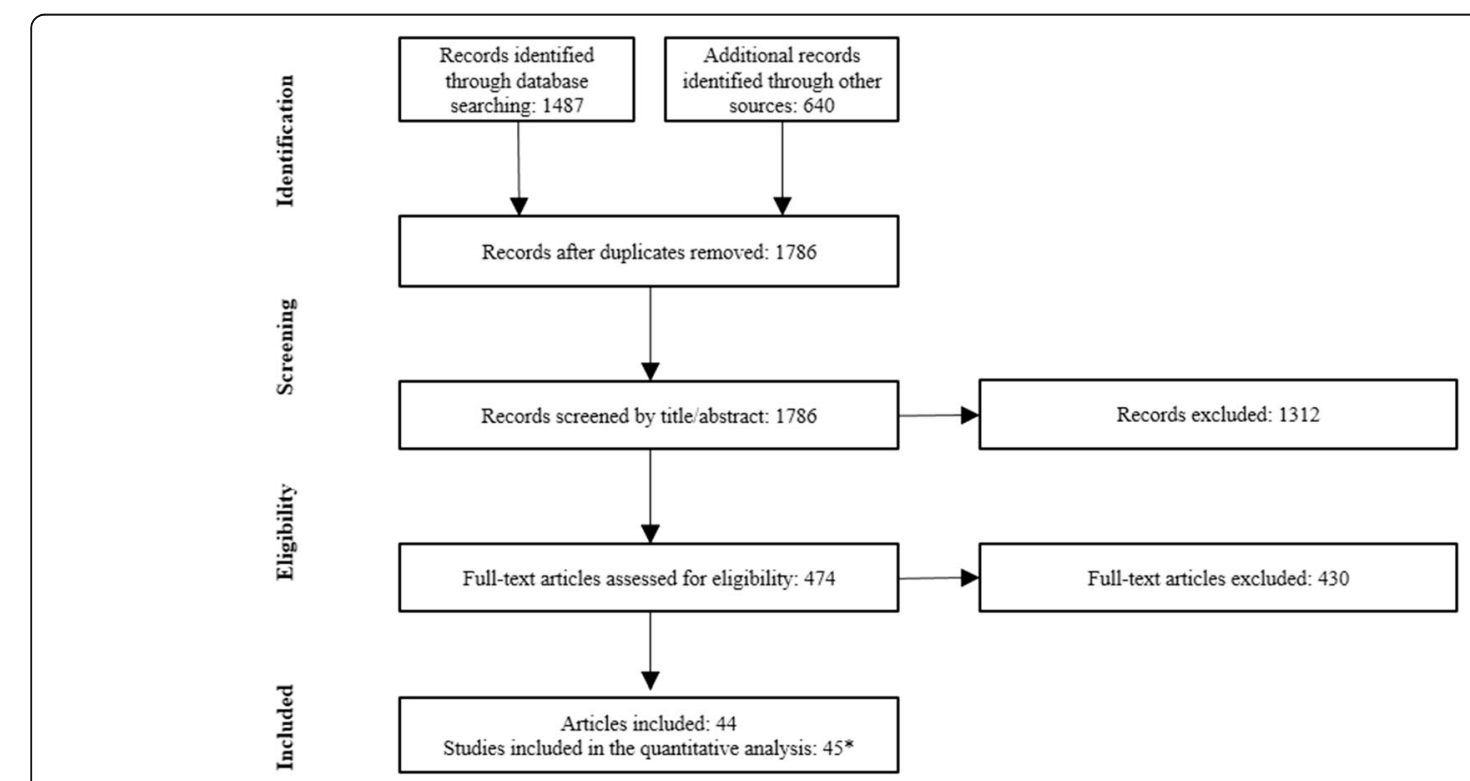

Fig. 1 PRISMA flow diagram of study selection 


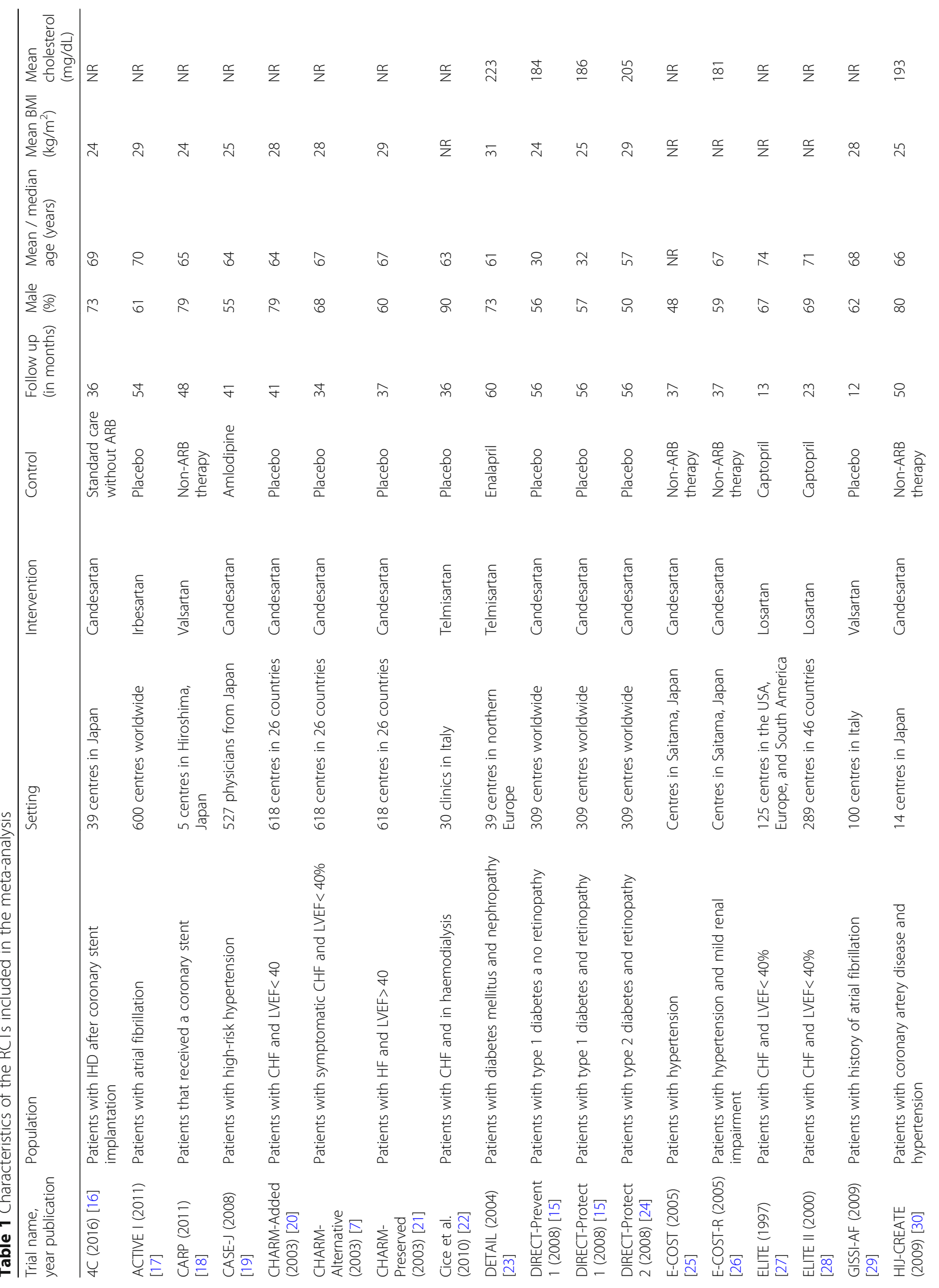




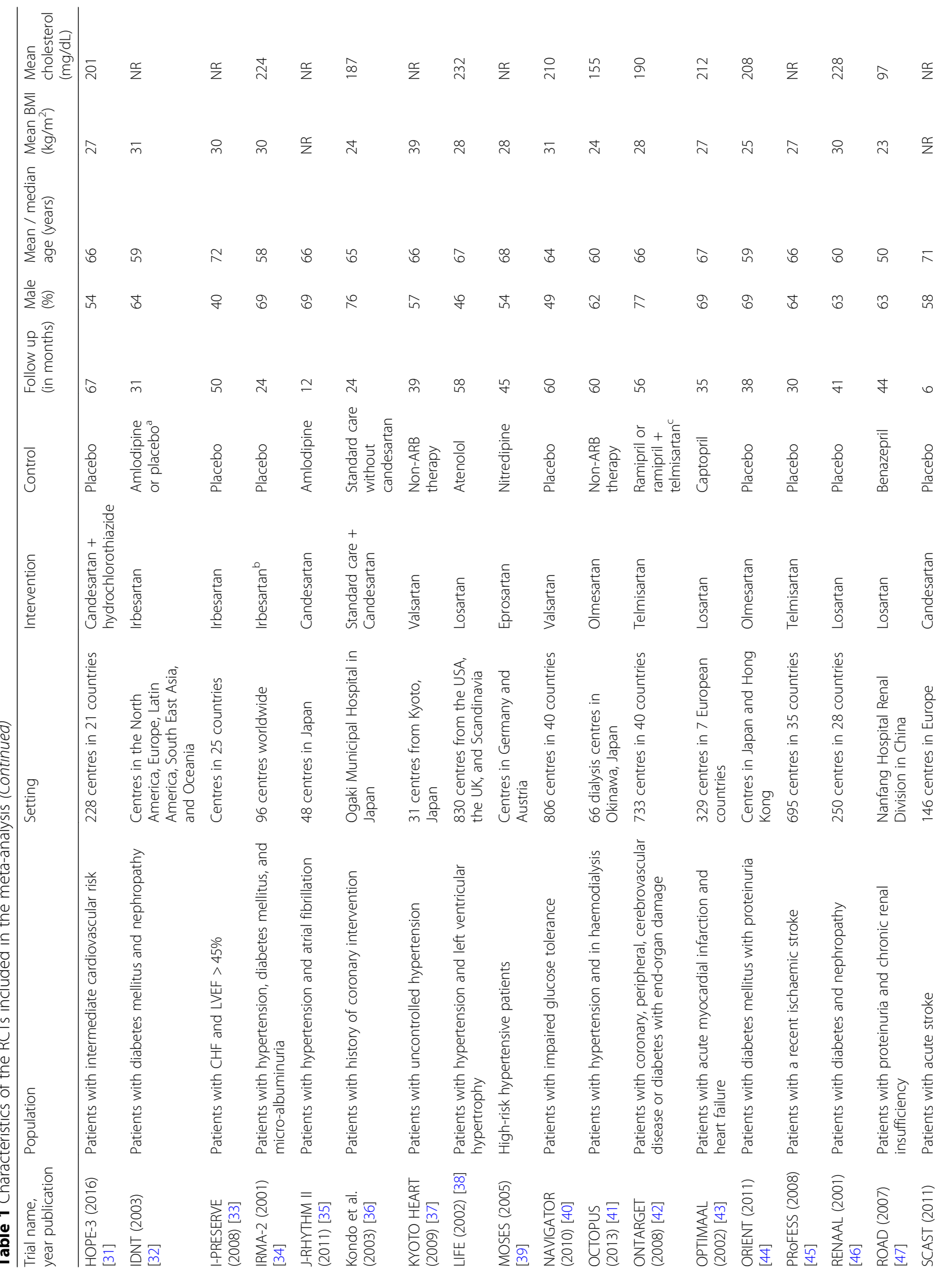




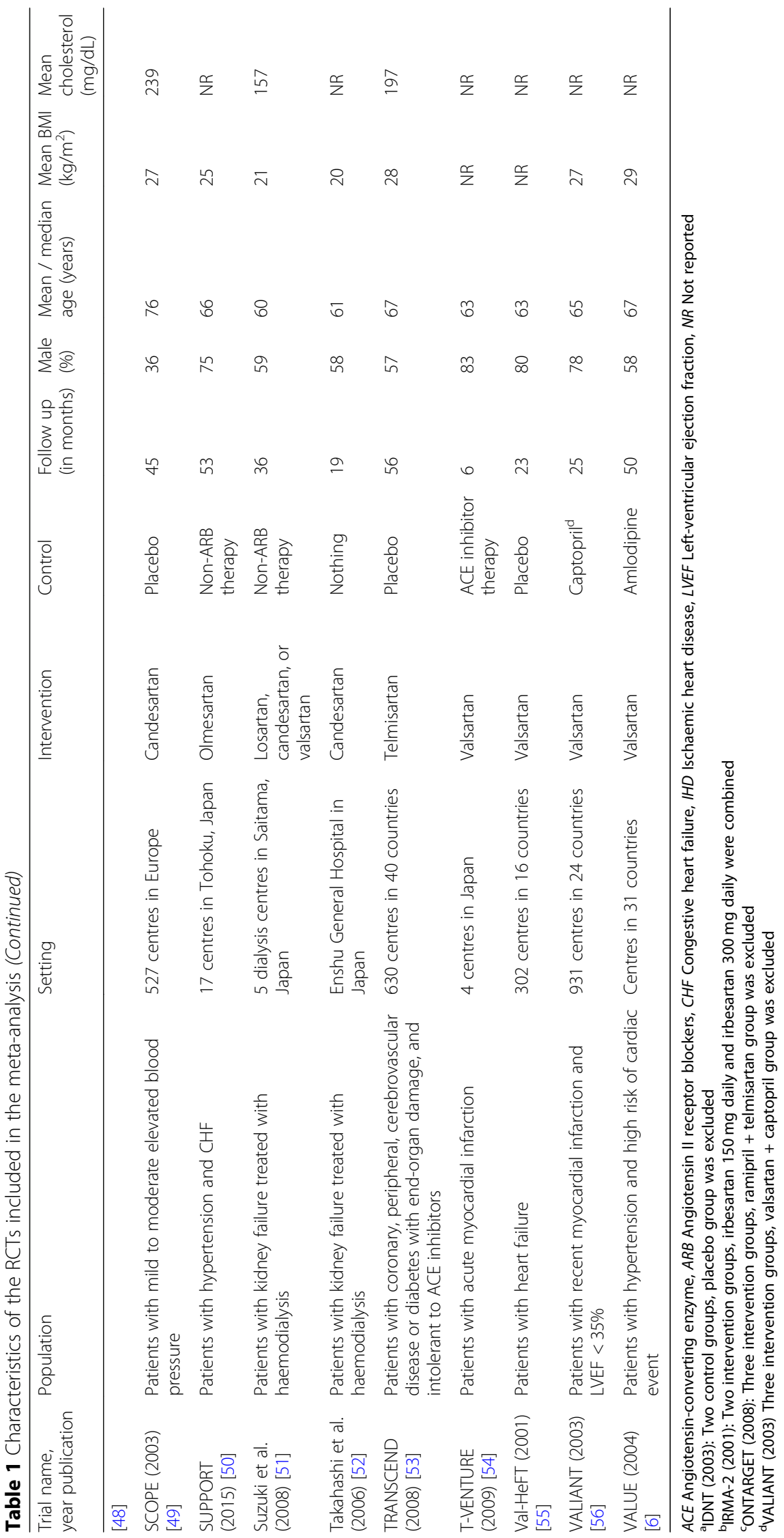




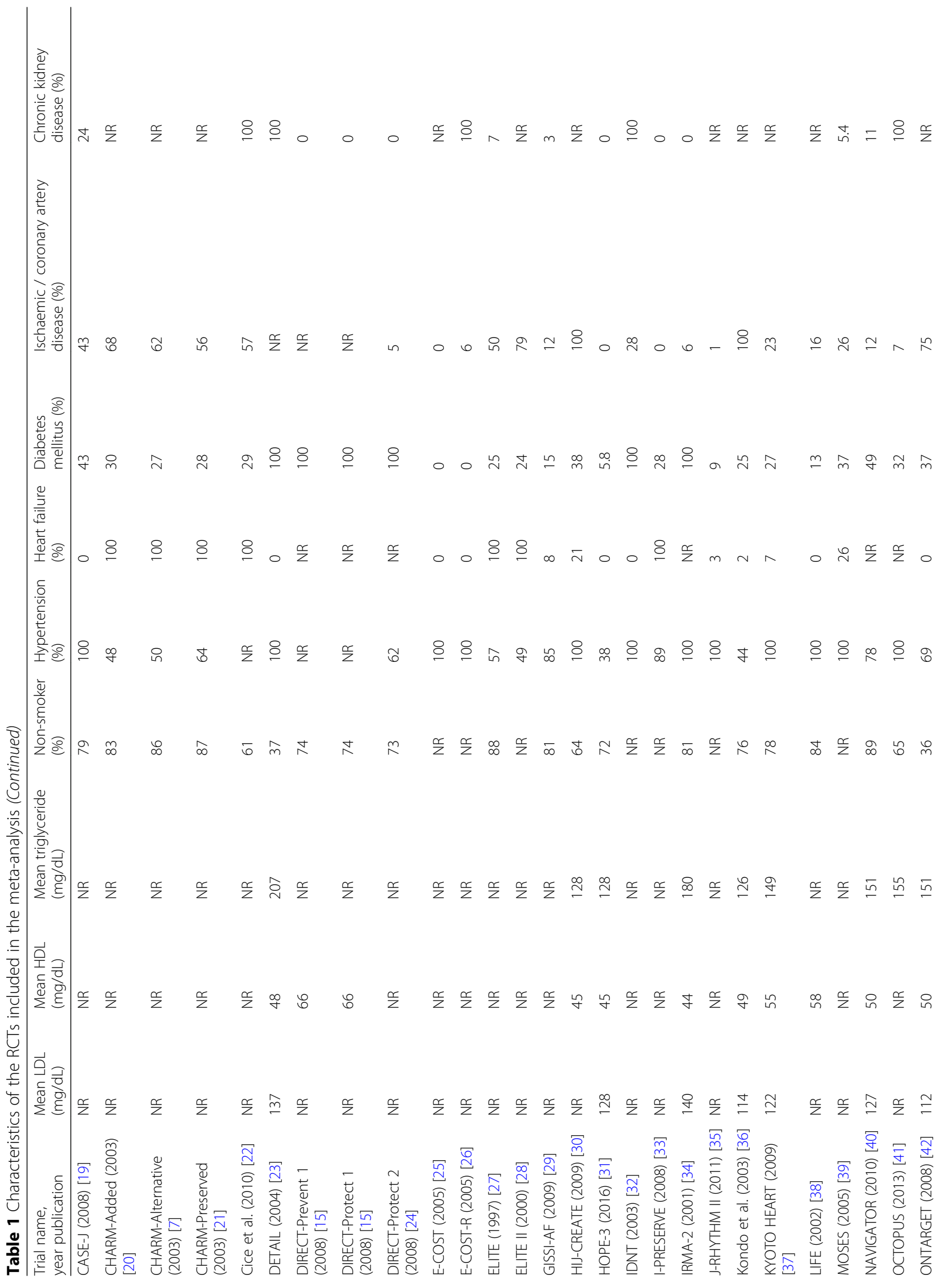




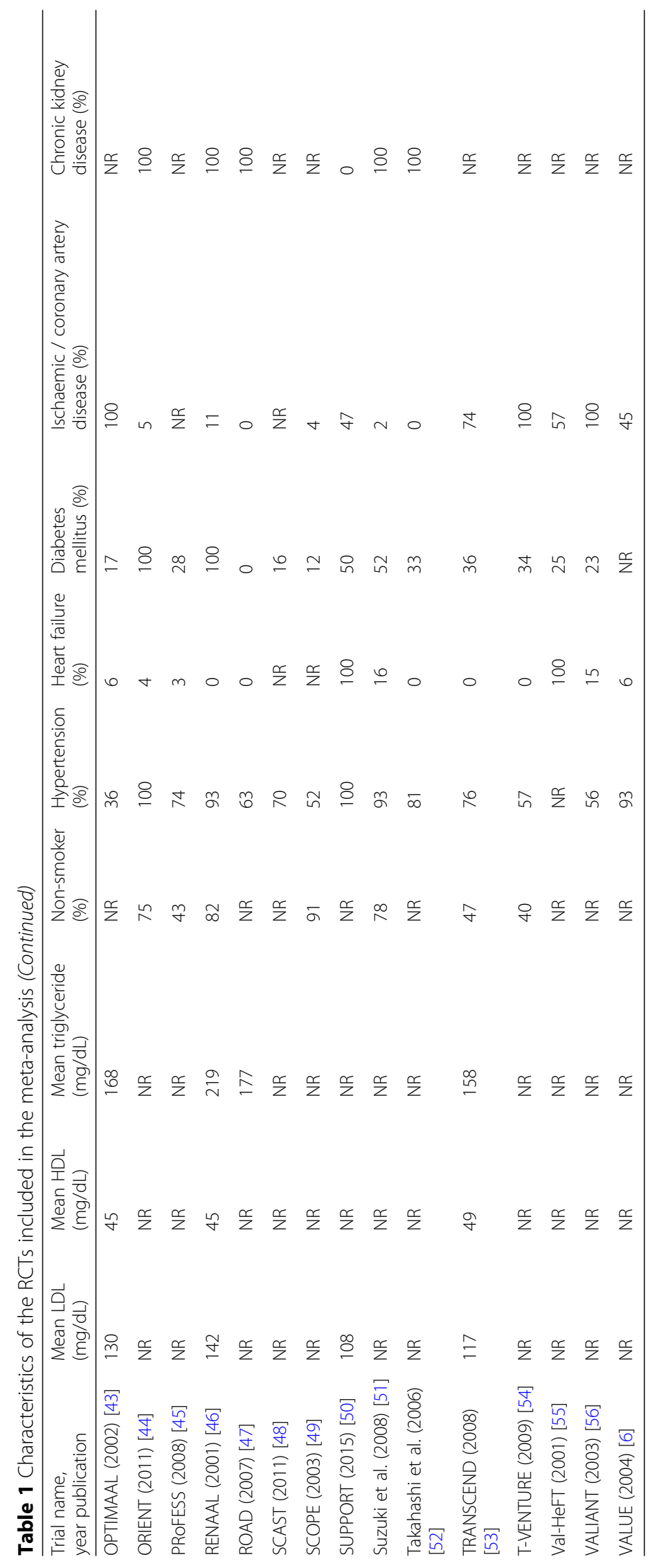


The inclusion of studies was restricted to human studies; RCTs comparing ARBs versus a control (either a placebo or another antihypertensive medication); followup of at least 12 months; and reported all-cause mortality, myocardial infarction, and stroke as outcomes. Recurrent myocardial infarction and stroke were also considered if the study only included patients that have had recently experienced myocardial infarction or stroke. Observational studies, studies where ARBs were not the first line of treatment, and conference abstracts were excluded.

\section{Data extraction and quality assessment}

The number of participants and the number events (i.e. all-cause mortality, myocardial infarction, and stroke) in each intervention group (ARBs [active] and non-ARBs [control]) were extracted. In addition, study characteristics (e.g. study sites and follow-up period) and participants' characteristics (e.g. mean age, proportion of males, mean BMI) were extracted. The Cochrane Collaboration's tool for assessing risk of bias in randomized trials [12] was used to assess the risk of bias of the included studies.

\section{Statistical analysis}

The outcomes of interest were the relative risks (RRs) of all-cause mortality, myocardial infarction, and stroke with ARBs compared to the control group. The inverse variance heterogeneity (IVhet) model was used to pool the effect size [13]. The $I^{2}$ index was used to assess heterogeneity among studies, an $I^{2}>50 \%$ was considered significant heterogeneity.

Sensitivity analyses were conducted to identify potential scenarios where ARBs increase the risk of all-cause mortality, myocardial infarction, and stroke. The following analyses restricting the meta-analysis to: control group (active medication, only ACE inhibitors, or placebo); follow-up period ( $\leq 40$ weeks or $>40$ weeks); proportion of males $(\leq 50 \%$ or $>50 \%)$; age ( $\leq 65$ years or $>65$ years); BMI (normal range or overweight/obese); elevated total cholesterol $(\geq 200 \mathrm{mg} / \mathrm{dL})$; elevated LDL $(\geq 120 \mathrm{mg} / \mathrm{dL})$; decreased HDL $(<50 \mathrm{mg} / \mathrm{dL})$; elevated triglyceride $(\geq 150 \mathrm{mg} / \mathrm{dL})$; proportion of smokers $(<25 \%$ or $\geq 25 \%$ ); only patients with hypertension; only patients with or without chronic heart failure; only patients with or without diabetes mellitus; only patients with ischemic/coronary artery disease; and only patients with chronic kidney disease.

Publication bias was assessed through visual inspection of funnel and Doi plots and statistically through the Egger's regression $p$-value and the LFK index [14]. All the analyses were conducted in Stata MP 14 (StataCorp, College Station, TX, USA).

\section{Result}

\section{Study selection and study characteristics}

One thousand seven hundred and eighty-six unique records were identified through the search strategy and the similarity search. Four hundred and seventy-four records remained after the title and abstract screening and 44. publications remained after the full-text screening.
A

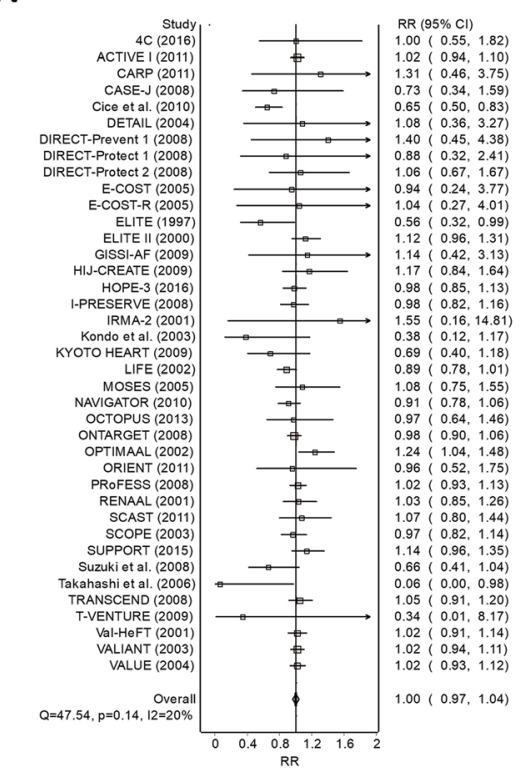

B

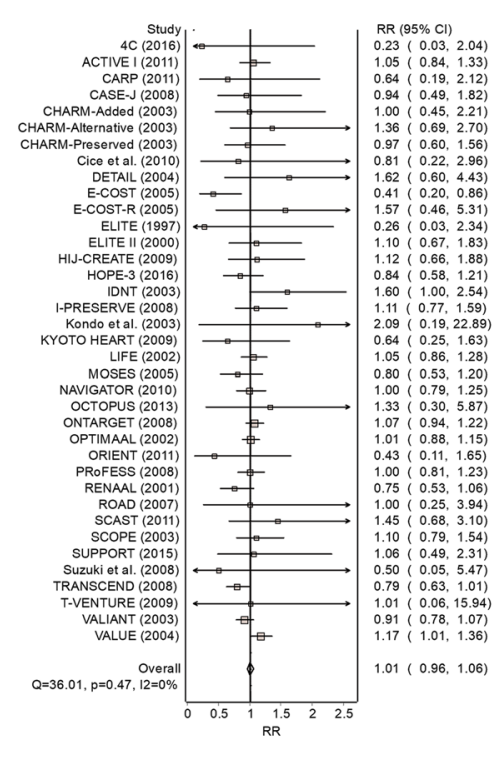

C

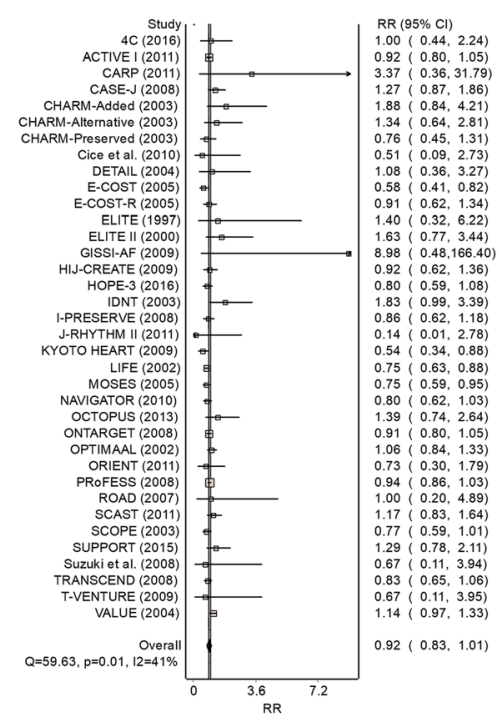

Fig. 2 Forest plot depicting the relative risk of ARBs on a) all-cause mortality, b) myocardial infarction, and c) stroke 
Table 2 Sensitivity analyses

\begin{tabular}{|c|c|c|c|c|c|c|c|c|c|}
\hline & All-cause mortality & & & Myocardial infar & & & Stroke & & \\
\hline & $\mathrm{RR}(95 \% \mathrm{Cl})$ & $p^{2}$ & $\mathrm{~N}$ & RR $(95 \% \mathrm{Cl})$ & $r^{2}$ & $\mathrm{~N}$ & RR $(95 \% \mathrm{Cl})$ & $P^{2}$ & $\mathrm{~N}$ \\
\hline Type of control & & & & & & & & & \\
\hline Placebo & $0.99(0.95-1.04)$ & 13 & 18 & $0.96(0.88-1.05)$ & 0 & 14 & $0.91(0.85-0.98)$ & 7 & 14 \\
\hline Active & $1.01(0.95-1.08)$ & 28 & 21 & $1.03(0.96-1.11)$ & 7 & 23 & $0.93(0.79-1.08)$ & 54 & 22 \\
\hline Active only ACE inhibitors & $1.04(0.95-1.13)$ & 46 & 8 & $1.01(0.93-1.09)$ & 0 & 9 & $0.98(0.88-1.10)$ & 0 & 8 \\
\hline Follow-up period & & & & & & & & & \\
\hline$\leq 40$ weeks & $1.01(0.91-1.14)$ & 51 & 19 & $0.98(0.88-1.10)$ & 12 & 18 & $0.94(0.74-1.20)$ & 40 & 18 \\
\hline$>40$ weeks & $1.00(0.96-1.03)$ & 0 & 20 & $1.03(0.96-1.10)$ & 0 & 19 & $0.90(0.82-1.00)$ & 45 & 18 \\
\hline Proportion of males & & & & & & & & & \\
\hline$\leq 50 \%$ & $0.93(0.86-1.00)$ & 0 & 6 & $1.02(0.85-1.22)$ & 37 & 5 & $0.76(0.68-0.84)$ & 0 & 5 \\
\hline$>50 \%$ & $1.02(0.97-1.06)$ & 23 & 33 & $1.01(0.95-1.07)$ & 0 & 32 & $0.96(0.87-1.05)$ & 28 & 31 \\
\hline Age & & & & & & & & & \\
\hline$\leq 65$ years & $0.98(0.88-1.09)$ & 32 & 18 & $0.95(0.85-1.06)$ & 0 & 15 & $1.03(0.80-1.34)$ & 22 & 12 \\
\hline$>65$ years & $1.01(0.98-1.05)$ & 10 & 20 & $1.04(0.98-1.10)$ & 0 & 21 & $0.92(0.84-1.00)$ & 41 & 23 \\
\hline BMl & & & & & & & & & \\
\hline Normal range & $0.84(0.60-1.19)$ & 31 & 7 & $0.81(0.41-1.57)$ & 0 & 6 & $1.21(0.77-1.90)$ & 0 & 5 \\
\hline Overweight and obese & $1.01(0.98-1.04)$ & 0 & 24 & $1.01(0.96-1.07)$ & 5 & 24 & $0.92(0.83-1.01)$ & 49 & 23 \\
\hline Elevated total cholesterol & & & & & & & & & \\
\hline$\geq 200 \mathrm{mg} / \mathrm{dL}$ & $0.98(0.91-1.05)$ & 15 & 10 & $0.99(0.91-1.08)$ & 0 & 8 & $0.82(0.74-0.91)$ & 6 & 7 \\
\hline Elevated LDL & & & & & & & & & \\
\hline$\geq 120 \mathrm{mg} / \mathrm{dL}$ & $1.01(0.90-1.14)$ & 36 & 7 & $0.97(0.87-1.07)$ & 0 & 6 & $0.86(0.70-1.07)$ & 45 & 5 \\
\hline Decreased HDL & & & & & & & & & \\
\hline$<50 \mathrm{mg} / \mathrm{dL}$ & $1.01(0.95-1.08)$ & 15 & 11 & $0.99(0.89-1.09)$ & 20 & 10 & $0.90(0.82-0.98)$ & 0 & 8 \\
\hline Elevated triglyceride & & & & & & & & & \\
\hline$\geq 150 \mathrm{mg} / \mathrm{dL}$ & $1.01(0.94-1.08)$ & 13 & 8 & $0.99(0.90-1.09)$ & 16 & 8 & $0.92(0.83-1.01)$ & 0 & 7 \\
\hline Proportion of smokers & & & & & & & & & \\
\hline$<25 \%$ & $0.91(0.84-0.98)$ & 2 & 12 & $0.99(0.88-1.11)$ & 0 & 13 & $0.81(0.67-0.99)$ & 41 & 12 \\
\hline$\geq 25 \%$ & $0.99(0.95-1.05)$ & 7 & 15 & $0.99(0.91-1.01)$ & 0 & 12 & $0.92(0.87-0.98)$ & 0 & 12 \\
\hline Hypertension & & & & & & & & & \\
\hline Only patients with hypertension & $0.98(0.89-1.07)$ & 0 & 12 & $1.02(0.80-1.29)$ & 27 & 12 & $0.82(0.66-1.03)$ & 57 & 13 \\
\hline Chronic heart failure (CHF) & & & & & & & & & \\
\hline Only patients without $\mathrm{CHF}$ & $0.97(0.92-1.03)$ & 0 & 11 & $0.99(0.83-1.18)$ & 43 & 12 & $0.85(0.73-1.00)$ & 47 & 11 \\
\hline Only patients with CHF & $1.00(0.85-1.19)$ & 75 & 6 & $1.06(0.86-1.32)$ & 0 & 8 & $1.04(0.81-1.32)$ & 14 & 8 \\
\hline Diabetes mellitus (DM) & & & & & & & & & \\
\hline Only patients without DM & $0.99(0.38-2.61)$ & 0 & 2 & $0.65(0.26-1.59)$ & 48 & 3 & $0.72(0.50-1.04)$ & 37 & 3 \\
\hline Only patients with DM & $1.04(0.88-1.23)$ & 0 & 7 & $0.99(0.53-1.80)$ & 67 & 4 & $1.31(0.73-2.35)$ & 30 & 3 \\
\hline Ischemic/coronary artery disease & & & & & & & & & \\
\hline Only patients with ischemic/coronary artery disease & $1.06(0.91-1.22)$ & 25 & 7 & $0.97(0.88-1.07)$ & 0 & 7 & $1.02(0.84-1.24)$ & 0 & 5 \\
\hline Chronic kidney disease & & & & & & & & & \\
\hline Only patients with chronic kidney disease & $0.86(0.66-1.12)$ & 50 & 8 & $0.99(0.71-1.41)$ & 20 & 9 & $1.08(0.83-1.39)$ & 0 & 8 \\
\hline
\end{tabular}

$C l$ confidence interval; $N$ number of studies; $R R$ relative risk; $A C E$ angiotensin-converting-enzyme Statistically significant results are emboldened 
The 44 publications reported data from 45 RCTs and 170,794 participants $(85,544$ participants in the ARB group and 85,250 participants in the placebo/control group) (Fig. 1). The publication by Chaturvedi et al. [15] reported findings from two RCTs, the DIRECT-Prevent 1 and DIRECT-Protect 1 studies.

Twenty four RCTs compared ARBs versus placebo, while 21 RCTs against an active medication. The majority of RCTs $(n=39)$ included a larger proportion of males (ranging from 54 to $90 \%$ ). Only two RCTs, DIRECTPrevent 1 and DIRECT-Protect 1 enrolled participants with a median age $<50$ years. Among the studies that reported the median BMI, only $22 \%$ had participants with a normal BMI $\left(<25 \mathrm{~kg} / \mathrm{cm}^{2}\right)$. Fourteen, nine, and eight RCTs included only patients with hypertension, chronic heart failure, and diabetes mellitus, respectively (Table 1). All-cause mortality, myocardial infarction, and stroke were assessed in 39, 37, and 36 RCTs.

\section{Quantitative synthesis}

After pooling all the available evidence, it was found that ARBs do not increase the risk of all-cause mortality (RR 1.00; 95\%CI 0.97-1.04), myocardial infarction (RR 1.01; 95\%CI 0.96-1.06), or stroke (RR 0.92; 95\%CI 0.83-1.01) (Fig. 2). Sensitivity analyses based on different study and participants characteristics showed no increase in risk of any of the three outcomes of interest. However, it was also noticed that ARBs did not reduce the risk of allcause mortality (RR 0.99 ; $95 \%$ CI $0.95-1.04$ ) or myocardial infarction (RR 0.96; 95\%CI $0.88-1.05$ ) when compared to placebo, ARBs only decreased the risk of stroke (RR 0.91; 95\%CI 0.85-0.98) (Table 2). Sensitivity analyses also revealed a decreased in all-cause mortality risk with ARBs when the proportion of smokers is small $(<$ 25\%) (RR 0.91; 95\%CI 0.84-0.98); and stroke in females (RR 0.76; 95\%CI 0.68-0.84), patients with elevated total cholesterol (RR 0.82; 95\%CI 0.82-0.91) and lower levels of HDL (RR 0.90; 95\%CI 0.80-0.98) (Table 2).

The most common deficiencies were no blinding of participants and personnel $(n=14 ; 31 \%)$, followed by no blinding of the outcome assessor $(n=10 ; 22 \%)$ and incomplete outcome data $(n=10 ; 22 \%)$. Overall, the RCTs showed low risk of bias except for E-COST [25], ECOST-R [26], and Kondo et al. [36] (S2).

The Doi plots revealed minor asymmetry for all-cause mortality ( $L F K$ index $=-1.24$ ) and myocardial infarction ( $L F K$ index $=-1.33$ ) for RCTs reporting favourable results for ARBs. No asymmetry was observed for stroke (supplementary material S3).

\section{Discussion}

Findings from previous RCTs were controversial, the VALUE [6] and the CHARM-alternative [7] trials found increase in myocardial infarction with ARBs compared to amlodipine and placebo, respectively. While other large RCTs such as the LIFE [38] and the RENAAL [46] trials found a decrease in all-cause of death and myocardial infarction with ARBs. In 2011, Bangalore et al. [57] conducted a meta-analysis on ARBs and the risk of myocardial infarction and found that ARBs do not increase the risk of cardiovascular events. Since then, multiple RCTs have been published; in our meta-analysis we pooled the most updated evidence (45 RCTs comprising of 170,794 participants - 8 RCTs and 23,000 more participants that Bangalore et al.) and corroborated that ARBs are safe medications as they do not increase the risk of all-cause mortality, myocardial infarction, or stroke. It is worth pointing out that our meta-analysis (in line with previous studies $[57,58]$ ) also found that ARBs do not reduce the risk of all-cause mortality and myocardial infarction when compared to placebo.

In addition, the safety profile of ARBs was examined in multiple scenarios by restricting the analysis to different study and participants characteristics (i.e. sensitivity analyses). In none of the cases, ARBs were found to increase the risk of all-cause mortality, myocardial infarction, and stroke. ARBs reduce the risk of all-cause mortality by $9 \%$ in populations with low prevalence of smokers and exerts a cerebrovascular protective effect in female patients and patients with abnormal total cholesterol or HDL.

Findings from our study are reassuring for patients and clinicians as ARBs are widely used to treat conditions such as hypertension, chronic kidney disease/kidney failure (especially in patients with diabetes mellitus), and heart failure. However, the findings need to be understood in light of some of the limitations. Only RCTs were included, but the possibility of confounding not accounted during the analysis of the RCTs cannot be completely ruled out. There was heterogeneity in the RCTs protocols (e.g. inclusion criteria, different ARBs, different doses, follow-up) that needs to be accounted in future research synthesis studies through individual patients meta-analysis.

\section{Conclusion}

In conclusion, our meta-analysis provides reassuring evidence for patients and clinicians that ARBs are safe drugs, and do not increase the risk of death, myocardial infarction, and stroke.

\section{Supplementary information}

Supplementary information accompanies this paper at https://doi.org/10. 1186/s12872-020-01466-5.

Additional file 1: S1. Search strategy $\mathbf{S 2}$. Risk of bias of the included studies S3. Doi (top) and funnel (bottom) plots for the studies assessing a) all-cause mortality, b) myocardial infarction, and c) stroke $\mathbf{S 4}$. 


\section{Abbreviations}

ARB: Angiotensin receptor blocker; ACE: Angiotensin-converting-enzyme; CVD: Cardiovascular disease; DALYs: Disability adjusted life years; IVhet: Inverse variance heterogeneity; RCT: Randomised controlled trial; RR: Relative risk

\section{Acknowledgments}

The publication of this article was funded by the Qatar National Library.

\section{Authors' contribution}

Conception and design of the study: LFK. Collection and assembly of the dataset: YW, RB, LFK. Analysis of the dataset and interpretation of results: YW, RB, NI, LFK. Manuscript writing: YW, RB, NI, LFK. Final approval of manuscript: YW, RB, NI, LFK

\section{Availability of data and materials}

he data used in the study was extracted from published studies.

\section{Ethics approval and consent to participate}

Not applicable, this is a systematic review and meta-analysis of published papers.

\section{Consent for publication}

Not applicable.

\section{Competing interests}

The authors declare that they have no competing interests.

\section{Author details}

'Department of Population Medicine, College of Medicine, QU Health, Qatar University, Doha, Qatar. ²Department of Public Health, College of Health Sciences, QU Health, Qatar University, Doha, Qatar. ${ }^{3}$ Research School of Population Health, ANU College of Health and Medicine, Australian National University, Acton, Australia.

\section{Received: 3 October 2019 Accepted: 5 April 2020}

Published online: 21 April 2020

\section{References}

1. Bansilal S, Castellano JM, Fuster V. Global burden of CVD: focus on secondary prevention of cardiovascular disease. Int J Cardiol. 2015;201(Suppl 1):S1-7.

2. World Health Organization. Global Health Observatory Data - Raised blood pressure. http://www.who.int/gho/ncd/risk_factors/blood_pressure_ prevalence_text/en/ (Accessed Sep 2019).

3. Suzanne Oparil RES. New approaches in the treatment of hypertension. Circ Res. 2015;116(6):1075.

4. Miklos Z, Molnar KK-Z, Evan H, Lott JLL, Malakauskas SM, Jennie Z, et al. ACE inhibitor and angiotensin receptor blocker use and mortality in patients with chronic kidney diseaseJ Am Coll Cardiol. 2013;63(7):650-8.

5. Schmieder RE, Ruilope LM, Barnett AH. Renal protection with angiotensin receptor blockers: where do we stand. J Nephrol. 2011;24(5):569-80.

6. Julius S, Kjeldsen SE, Weber M, Brunner HR, Ekman S, Hansson L, et al. Outcomes in hypertensive patients at high cardiovascular risk treated with regimens based on valsartan or amlodipine: the VALUE randomised trial. Lancet (London, England). 2004;363(9426):2022-31.

7. Granger CB, McMurray JJ, Yusuf S, Held P, Michelson EL, Olofsson B, et al. Effects of candesartan in patients with chronic heart failure and reduced left-ventricular systolic function intolerant to angiotensin-convertingenzyme inhibitors: the CHARM-alternative trial. Lancet (London, England). 2003;362(9386):772-6.

8. Yusuf S, Teo K, Anderson C, Pogue J, Dyal L, Copland I, et al. Effects of the angiotensin-receptor blocker telmisartan on cardiovascular events in high-risk patients intolerant to angiotensin-converting enzyme inhibitors: a randomised controlled trial. Lancet (London, England). 2008;372(9644):1174-83.

9. Bangalore S, Fakheri R, Toklu B, Ogedegbe G, Weintraub H, Messerli FH. Angiotensin-converting enzyme inhibitors or angiotensin receptor blockers in patients without heart failure? Insights from 254,301 patients from randomized trials. Mayo Clin Proc. 2016;91(1):51-60.
10. Moher D, Liberati A, Tetzlaff J, Altman DG. Preferred reporting items for systematic reviews and meta-analyses: the PRISMA statement. PLoS Med. 2009;6(7):e1000097.

11. Ouzzani M, Hammady H, Fedorowicz Z, Elmagarmid A. Rayyan-a web and mobile app for systematic reviews. Syst Rev. 2016;5(1):210.

12. Higgins JP, Altman DG, Gotzsche PC, Juni P, Moher D, Oxman AD, et al. The Cochrane Collaboration's tool for assessing risk of bias in randomised trials. BMJ (Clinical research ed). 2011;343:d5928.

13. Doi SA, Barendregt JJ, Khan S, Thalib L, Williams GM. Advances in the metaanalysis of heterogeneous clinical trials I: the inverse variance heterogeneity model. Contemp Clin Trials. 2015;45(Pt A):130-8.

14. Furuya-Kanamori L, Barendregt JJ, Doi SAR. A new improved graphical and quantitative method for detecting bias in meta-analysis. Intl J Evid-Based Healthc. 2018;16(4):195-203.

15. Chaturvedi N, Porta M, Klein R, Orchard T, Fuller J, Parving HH, et al. Effect of candesartan on prevention (DIRECT-prevent 1) and progression (DIRECTprotect 1) of retinopathy in type 1 diabetes: randomised, placebo-controlled trials. Lancet (London, England). 2008;372(9647):1394-402.

16. Sakamoto T, Ogawa H, Nakao K, Hokimoto S, Tsujita K, Koide S, et al. Impact of candesartan on cardiovascular events after drug-eluting stent implantation in patients with coronary artery disease: the 4C trial. J Cardiol. 2016;67(4):371-7.

17. Yusuf S, Healey JS, Pogue J, Chrolavicius S, Flather M, Hart RG, et al. Irbesartan in patients with atrial fibrillation. N Engl J Med. 2011;364(10):928-38.

18. Okada T, Yamamoto H, Okimoto T, Otsuka M, Ishibashi K, Dohi Y, et al. Beneficial effects of valsartan on target lesion revascularization after percutaneous coronary interventions with bare-metal stents. Circ J. 2011; 75(7):1641-8

19. Ogihara T, Nakao K, Fukui T, Fukiyama K, Ueshima K, Oba K, et al. Effects of candesartan compared with amlodipine in hypertensive patients with high cardiovascular risks: candesartan antihypertensive survival evaluation in Japan trial. Hypertension (Dallas, Tex : 1979). 2008;51(2):393-8.

20. McMurray JJ, Ostergren J, Swedberg K, Granger CB, Held P, Michelson EL, et al. Effects of candesartan in patients with chronic heart failure and reduced left-ventricular systolic function taking angiotensin-convertingenzyme inhibitors: the CHARM-added trial. Lancet (London, England). 2003; 362(9386):767-71.

21. Yusuf S, Pfeffer MA, Swedberg K, Granger CB, Held P, McMurray JJ, et al. Effects of candesartan in patients with chronic heart failure and preserved left-ventricular ejection fraction: the CHARM-preserved trial. Lancet (London, England). 2003;362(9386):777-81.

22. Cice G, Di Benedetto A, D'Isa S, D'Andrea A, Marcelli D, Gatti E, et al. Effects of telmisartan added to angiotensin-converting enzyme inhibitors on mortality and morbidity in hemodialysis patients with chronic heart failure a double-blind, placebo-controlled trial. J Am Coll Cardiol. 2010;56(21):1701-8.

23. Barnett AH, Bain SC, Bouter P, Karlberg B, Madsbad S, Jervell J, et al. Angiotensin-receptor blockade versus converting-enzyme inhibition in type 2 diabetes and nephropathy. N Engl J Med. 2004;351(19):1952-61.

24. Sjolie AK, Klein R, Porta M, Orchard T, Fuller J, Parving HH, et al. Effect of candesartan on progression and regression of retinopathy in type 2 diabetes (DIRECT-protect 2): a randomised placebo-controlled trial. Lancet (London, England). 2008;372(9647):1385-93.

25. Suzuki H, Kanno Y. Effects of candesartan on cardiovascular outcomes in Japanese hypertensive patients. Hypertens Res. 2005;28(4):307-14.

26. Nakamura T, Kanno Y, Takenaka T, Suzuki H. An angiotensin receptor blocker reduces the risk of congestive heart failure in elderly hypertensive patients with renal insufficiency. Hypertens Res. 2005;28(5):415-23.

27. Pitt B, Segal R, Martinez FA, Meurers G, Cowley AJ, Thomas I, et al. Randomised trial of losartan versus captopril in patients over 65 with heart failure (evaluation of losartan in the elderly study, ELITE). Lancet (London, England). 1997;349(9054):747-52.

28. Pitt B, Poole-Wilson PA, Segal R, Martinez FA, Dickstein $K$, Camm AJ, et al. Effect of losartan compared with captopril on mortality in patients with symptomatic heart failure: randomised trial--the losartan heart failure survival study ELITE II. Lancet (London, England). 2000;355(9215):1582-7.

29. Disertori M, Latini R, Barlera S, Franzosi MG, Staszewsky L, Maggioni AP, et al. Valsartan for prevention of recurrent atrial fibrillation. N Engl J Med. 2009; 360(16):1606-17.

30. Kasanuki H, Hagiwara N, Hosoda S, Sumiyoshi T, Honda T, Haze K, et al. Angiotensin II receptor blocker-based vs. non-angiotensin II receptor blocker-based therapy in patients with angiographically documented 
coronary artery disease and hypertension: the heart Institute of Japan Candesartan Randomized Trial for evaluation in coronary artery disease ( $\mathrm{HIJ}$ CREATE). Eur Heart J. 2009;30(10):1203-12.

31. Lonn EM, Bosch J, Lopez-Jaramillo P, Zhu J, Liu L, Pais P, et al. Bloodpressure lowering in intermediate-risk persons without cardiovascular disease. N Engl J Med. 2016;374(21):2009-20.

32. Berl T, Hunsicker LG, Lewis JB, Pfeffer MA, Porush JG, Rouleau JL, et al. Cardiovascular outcomes in the Irbesartan diabetic nephropathy trial of patients with type 2 diabetes and overt nephropathy. Ann Intern Med. 2003:138(7):542-9.

33. Massie BM, Carson PE, McMurray JJ, Komajda M, McKelvie R, Zile MR, et al. Irbesartan in patients with heart failure and preserved ejection fraction. $N$ Engl J Med. 2008;359(23):2456-67.

34. Parving $\mathrm{H}-\mathrm{H}$, Lehnert $\mathrm{H}$, Bröchner-Mortensen J, Gomis R, Andersen S, Arner $P$. The effect of Irbesartan on the development of diabetic nephropathy in patients with type 2 diabetes. N Engl J Med. 2001;345(12):870-8.

35. Yamashita T, Inoue H, Okumura K, Kodama I, Aizawa Y, Atarashi H, et al. Randomized trial of angiotensin II-receptor blocker vs. dihydropiridine calcium channel blocker in the treatment of paroxysmal atrial fibrillation with hypertension (J-RHYTHM II study). Europace. 2011;13(4):473-9.

36. Kondo J, Sone T, Tsuboi H, Mukawa H, Morishima I, Uesugi M, et al. Effects of low-dose angiotensin II receptor blocker candesartan on cardiovascular events in patients with coronary artery disease. Am Heart J. 2003;146(6):E20.

37. Sawada T, Yamada H, Dahlof B, Matsubara $H$. Effects of valsartan on morbidity and mortality in uncontrolled hypertensive patients with high cardiovascular risks: KYOTO HEART study. Eur Heart J. 2009;30(20):2461-9.

38. Dahlof B, Devereux RB, Kjeldsen SE, Julius S, Beevers G, de Faire U, et al. Cardiovascular morbidity and mortality in the losartan intervention for endpoint reduction in hypertension study (LIFE): a randomised trial against atenolol. Lancet (London, England). 2002;359(9311):995-1003.

39. Schrader J, Luders S, Kulschewski A, Hammersen F, Plate K, Berger J, et al. Morbidity and mortality after stroke, Eprosartan compared with Nitrendipine for secondary prevention: principal results of a prospective randomized controlled study (MOSES). Stroke. 2005;36(6):1218-26.

40. The NAVIGATOR Study Group. Effect of valsartan on the incidence of diabetes and cardiovascular events. N Engl J Med. 2010;362(16):1477-90.

41. Iseki K, Arima H, Kohagura K, Komiya I, Ueda S, Tokuyama K, et al. Effects of angiotensin receptor blockade (ARB) on mortality and cardiovascular outcomes in patients with long-term haemodialysis: a randomized controlled trial. Nephrol Dial Transplant. 2013;28(6):1579-89.

42. Yusuf S, Teo KK, Pogue J, Dyal L, Copland I, Schumacher H, et al. Telmisartan, ramipril, or both in patients at high risk for vascular events. $\mathrm{N}$ Engl J Med. 2008;358(15):1547-59.

43. Dickstein K, Kjekshus J. Effects of losartan and captopril on mortality and morbidity in high-risk patients after acute myocardial infarction: the OPTIMAAL randomised trial. Optimal trial in myocardial infarction with angiotensin II antagonist losartan. Lancet (London, England). 2002;360(9335): 752-60.

44. Imai E, Chan JC, Ito S, Yamasaki T, Kobayashi F, Haneda M, et al. Effects of olmesartan on renal and cardiovascular outcomes in type 2 diabetes with overt nephropathy: a multicentre, randomised, placebo-controlled study. Diabetologia. 2011;54(12):2978-86.

45. Yusuf S, Diener HC, Sacco RL, Cotton D, Ounpuu S, Lawton WA, et al. Telmisartan to prevent recurrent stroke and cardiovascular events. N Engl J Med. 2008;359(12):1225-37.

46. Brenner BM, Cooper ME, de Zeeuw D, Keane WF, Mitch WE, Parving HH, et al. Effects of losartan on renal and cardiovascular outcomes in patients with type 2 diabetes and nephropathy. N Engl J Med. 2001;345(12):861-9.

47. Hou FF, Xie D, Zhang X, Chen PY, Zhang WR, Liang M, et al. Renoprotection of optimal Antiproteinuric doses (ROAD) study: a randomized controlled study of benazepril and losartan in chronic renal insufficiency. J Am Soc Nephrol. 2007;18(6):1889-98.

48. Sandset EC, Bath PM, Boysen G, Jatuzis D, Korv J, Luders S, et al. The angiotensin-receptor blocker candesartan for treatment of acute stroke (SCAST): a randomised, placebo-controlled, double-blind trial. Lancet (London, England). 2011;377(9767):741-50.

49. Lithell H, Hansson L, Skoog I, Elmfeldt D, Hofman A, Olofsson B, et al. The study on cognition and prognosis in the elderly (SCOPE): principal results of a randomized double-blind intervention trial. J Hypertens. 2003;21(5):875-86.

50. Sakata Y, Shiba N, Takahashi J, Miyata S, Nochioka K, Miura M, et al. Clinical impacts of additive use of olmesartan in hypertensive patients with chronic heart failure: the supplemental benefit of an angiotensin receptor blocker in hypertensive patients with stable heart failure using olmesartan (SUPPORT) trial. Eur Heart J. 2015;36(15):915-23.

51. Suzuki H, Kanno Y, Sugahara S, Ikeda N, Shoda J, Takenaka T, et al. Effect of angiotensin receptor blockers on cardiovascular events in patients undergoing hemodialysis: an open-label randomized controlled trial. Am J Kidney Dis. 2008;52(3):501-6.

52. Takahashi A, Takase H, Toriyama T, Sugiura T, Kurita Y, Ueda R, et al. Candesartan, an angiotensin II type-1 receptor blocker, reduces cardiovascular events in patients on chronic haemodialysis--a randomized study. Nephrol Dial Transplant. 2006;21(9):2507-12.

53. The Telmisartan Randomised AssessmeNt Study in ACE iNtolerant subjects with cardiovascular Disease (TRANSCEND). Effects of the angiotensinreceptor blocker telmisartan on cardiovascular events in high-risk patients intolerant to angiotensin-converting enzyme inhibitors: a randomised controlled trial. Lancet. 2008;372:1174-83.

54. Suzuki H, Geshi E, Nanjyo S, Nakano H, Yamazaki J, Sato N, et al. Inhibitory effect of valsartan against progression of left ventricular dysfunction after myocardial infarction: T-VENTURE study. Circ J. 2009;73(5):918-24.

55. Cohn JN, Tognoni G. A randomized trial of the angiotensin-receptor blocker valsartan in chronic heart failure. N Engl J Med. 2001;345(23):1667-75.

56. Pfeffer MA, McMurray JJV, Velazquez EJ, Rouleau J-L, Køber L, Maggioni AP, et al. Valsartan, captopril, or both in myocardial infarction complicated by heart failure, left ventricular dysfunction, or both. N Engl J Med. 2003; 349(20):1893-906

57. Bangalore S, Kumar S, Wetterslev J, Messerli FH. Angiotensin receptor blockers and risk of myocardial infarction: meta-analyses and trial sequential analyses of 147020 patients from randomised trials. BMJ (Clinical research ed). 2011;342:d2234.

58. Strauss MH, Hall AS. Angiotensin receptor blockers do not reduce risk of myocardial infarction, cardiovascular death, or Total mortality: further evidence for the ARB-MI paradox. Circulation. 2017;135(22):2088-90.

\section{Publisher's Note}

Springer Nature remains neutral with regard to jurisdictional claims in published maps and institutional affiliations.

Ready to submit your research? Choose BMC and benefit from:

- fast, convenient online submission

- thorough peer review by experienced researchers in your field

- rapid publication on acceptance

- support for research data, including large and complex data types

- gold Open Access which fosters wider collaboration and increased citations

- maximum visibility for your research: over $100 \mathrm{M}$ website views per year

At BMC, research is always in progress.

Learn more biomedcentral.com/submissions 